\title{
Bọlanle Awẹ: The Matriarch of Feminist History
}

\author{
Toyin Falọla \\ University Distinguished Teaching Professor \\ Jacob and Frances Sanger Mossiker Chair in the Humanities \\ The University of Texas at Austin \\ toyinfalola@austin.utexas.edu
}

At the celebration of the $70^{\text {th }}$ anniversary of the founding of the University of Ibadan, famous historian, Professor Bọlanle Awẹ was conferred with a well-deserved honorary doctorate degree. For both Professor Awẹ and even Nigeria's premier university, this great honor is a fitting tribute to mark the anniversary of the institution of learning that has been central to the intellectual history of Nigeria. The University of Ibadan has done well to select Professor Awe for this honor. Her earnestness and intelligence are beyond doubts. There is no gainsaying disputing her warmth, her magnetism. I have known her since the 1970s-she remains consistent in the exhibition of positive values, in the promotion of Yoruba culture, and the advancement of the scholarly enterprise.

Professor Awe is a woman with multiple career paths as a historian, an educator, a teacher, an administrator, and a social advocate for women-and indeed, human-causes, all of which she has distinguished herself at and inspired many generations of scholars and young women. Awẹ is Nigeria's first female professor of history, one of the first few female lecturers in Nigeria, and the most towering pioneer of the study of women's history in Nigeria. When history thrusts a minority in the role of a pioneer such as Awe was at the start of her career, one can do either of two things: enjoy the status, soak in all the fame and attention that comes with the position, and, at some point, begin to even assume that you are distinctively singular. Or, from that attained position as a minority and front-liner, begin to uproot the weeds that choke other women and prevent them from attaining their potentials and blaze a trail that others behind her would be fearless to follow on. Awe chose the latter and it has made all the difference to her, to other women and scholars, and to the 
discipline of history. Whether she consciously identifies as feminist or not, it is fitting to describe her as a feminist historian because of the prodigious scholarship and advocacy projects she has gifted us with in this respect.

Traditionally, the disciplines of history were male-dominated arenas. History books of all shades were written by men, for men, and about men. The reasoning and the introspection that the learning of history makes available to us were refracted from the lens that promoted mostly male history with women relegated to the margins as supporting cast whose perspectives and participation in the event of history were not deemed worthy of critical analysis. Thus, the discipline became a self-reproducing cycle of knowledge where the historical accomplishments of men were privileged while those of women were muted, and having established that foundation, male history became the defining lens through which we understand history-as a discipline, as an event, and as intellectual foundations through which we build the society. For Africans for whom history was not written down in books initially, women who lived in the past might as well have become dud statues, mere props and silent witnesses in a world where men did great and terrible things. Awe was one of those pioneer women who began to use the master's tools of academic knowledge and power to demolish the master's house built on male hegemony. Having done fascinating research into aspects of Ibadan, Yoruba, and African history, she turned the lights of her knowledge into women's history.

She committed her academic efforts to challenging Nigeria's stifling patriarchy by using her research and social capital to highlight women and their place in history. One of her biggest efforts in this field is her research into the history of Efunșetan Aniwura, the famous Iyalode of Ibadan, whose after-death historical revisionism has made her a tragic figure of history. Awẹ dug into the life and times of Efunșetan Aniwura to counter the creative account of Akinwunmi Isola, the late distinguished playwright and literary scholar, whose version of the story was being taken in some quarters as actual historical narration of the woman's life. The work documents the wealth, the glory, the industry of Efunșetan Aniwura and how she was such a dominant force in a male-dominated world, an effort that tried to retrieve her from the rubble of creative injustice Isola's play had buried her. Awe is famous for being the scholar to challenge Akinwumi Isola, on his characterization of Ẹfunșetan Aniwura in his famous play: Efúnșetán Aníwúrà: İyálóde İbàdàn, as an evil woman without any redeeming value. She highlighted the temporality E़funșetan Aniwura existed in and argued that the evils ascribed to her were not in isolation of the context in which the woman lived. Isola took the correction to heart and when the book was made into a film, her critique influenced the way the ending of the story was depicted differently from the book. 
From the time Professor Awe started her own formal education and came of age to understand the nature of our society, the education of women and girls in Nigeria has been a passion for her. She started propagating women's education as a civic right long before it became a popular course and she would eventually be instrumental in the establishment of the Nigerian Ministry of Women's Affairs. Awẹ has been a fierce challenger of the predominant maleness of the field of history and also, passionately advocated for the writing of women's history. She embarked on the task of retrieval of the history of pre-colonial women that had hitherto been silenced by the male-dominated field despite the abundant literature available on men and their activities.

At various fora, she has challenged the sidelining of women's history and even when feminist activism became a popular cause, she was also one of the first set of people to critique the Western, liberal feminist position which universalize women's subjugation under patriarchal rule. She pointed out that while women all over the world were constrained by patriarchy, the terms under which they are being held down varied from culture to culture. Therefore, rather than overshadow the issues of women in specific contexts by universalizing it, it is better to treat their causes by the history of their individual cultures instead. She was one of those who first called for a de-colonization of the fields of history, arguing that African history is best told from the perspective of Africans who are intricately connected to their local communities and are better interpreters of their own stories than anyone.

She has not only researched and written about women, she has lived the ideals she strove for through her academic work. For instance, she played a vital role in the establishment of WORDOC-Women's Research and Documentation Center at the Institute of African Studies, University of Ibadan. WORDOC is a resource center for research in women's and gender studies, and also serves as an advocacy group on causes that affect women in the Nigerian social and political sphere. WORDOC provides documentation on issues that affect women, creates opportunities, and works to influence state policy to positively affect women. WORDOC is one of the very few research centers available in Nigeria that focuses on women and their causes. Today, Awe is still advocating for the broader and institutionalized studies of gender in Nigerian universities to illuminate the social, political, economic, and cultural factors that-and continue to-hinder Nigerian and African women from taking their rightful places as citizens with enshrined and guaranteed rights. She has tons of work in that regard some of which include: University Education For Women In Nigeria (1964); Nigerian Women And Development In Retrospect (1989); Historical Patterns, Customs and Traditions Restricting Access of Girls to Education (1990); The Role of Nigerian Women in Management in the 90s (1990); Writing Women Into History: The Nigerian Experience 
(1991); Evaluation of Selected Women Economic Adjustment Programs (1997); Women's Rights and Human Rights (1995); Nigerian Women In Historical Perspective (1992); The Iyalode in the Traditional Yoruba Political System (2005).

Professor Awe is one of Ibadan city's most priceless jewels. Ibadan has produced many outstanding academics and other shining stars, but Awẹ stands out as one of the greatest scions of Ibadan who has made the city proud time and time again. Her honorary doctorate award is as much the privilege of the University of Ibadan as it is an honor to her. She has had a full life and the sum of her career represents the intersection between intellectualism, activism, administrative perspicacity, and continuing relevance to her immediate and external community. A long time ago, during the era of the military, Awe served as the Oyo State Commissioner of Education, and became the best the State has ever had.

In the course of her career as both a historian and an academic and an administrator, she has treated the art of casting the eyes of insight backward on the road that brought us to this point we inhabit in history as more than an academic exercise. She believed that history is a necessary precursor to African modernity and development. She has used her intellectualism and foremost learning to engage her society on many fronts-education, gender issues, cultural nationalism, and national development. She has zealously committed all her scholarship and social influence on the causes that advance social progress and ideals.

Awe represents a difference in the Nigerian academic world, the difference of antidote: decorum instead of decadence; comity rather than chaos; decency rather than animosity. If her male peers stand in the progress of others, she opens doors for them. Today, she stands taller than the male gatekeepers.

Congratulations, Professor Bọlanle Awẹ, the İyálóde of İtàn, the İyágúnwà of Ibadan, on this well-deserved honor. The light you have lit in our hearts and our heads have not gone out and we-along with others that you nurtured-will continue to shine the torch everywhere on this planet earth. You are the Moremi of our time and space; I give my bow to your sagely presence with these few lines of exhortation:

A reign of terror almost filled the land

Our heritage almost blurred off into the air

We were almost condemned to servitude

But for you, Mọremi

You saved the day with a huge cost

Till the end of time, we owe you homage 
This is a chorus of glorification, Iyyáa wa, a hymn of hurrah for us to sing in unison as we puff, to be followed by a series of odes, one ode of laudation, another of exaltation, and the next on approbation until we close the devotion with citations and encomiums.

Don't stress yourself about Nigeria; instead, let your consolation be in those wonderful words of the wise king:

Do not say, "Why were the old days better than these?"

For it is not wise to ask such questions. Ecclesiastes, 7:10

Màmá Àgbà, rejoice! 